\title{
In vitro evaluation of antifungal activity of Ageratum conyzoides, Basella alba and Mitracarpus villosus on the strain of Lasiodiplodia theobromae in the Kisangani Region / D R Congo
}

KWEMBE J.T.K. *, ASUMANI M.K., ONAUTSHU O., MPIANA P.T., HAESAERT G.

KWEMBE KONGANAPE Jean-Trésor : PhD student, Supervisor, Congolese (D.R), Department of Chemistry, Faculty of Sciences, University of Kisangani, B.P. 2012 Kisangani, R D Congo jeantresorkwe@gmail.com

ASUMANI KAMUSOSE Martin: Research Assistant, Congolese (D.R), Department of Biotechnological Sciences, Faculty of Sciences, University of Kisangani, B.P. 2012 Kisangani, D.R. of Congo

ONAUTSHU ODIMBA Didy: PhD, Professor, Congolese (D.R), Department of Biotechnological Sciences, Faculty of Sciences, University of Kisangani, B.P. 2012 Kisangani, D.R. of Congo.

MPIANA TSHIMAKINDA Pius: PhD, Professor, Congolese (D.R), Department of Chemistry, Faculty of Sciences, University of Kinshasa, B.P. 190 Kinshasa XI, D.R. of Congo

HAESAERT GEERT: PhD, Professor, Department of Plants and Cultures, Faculty of Biosciences Engineering, University of Ghent, Ghent 9000, Belgium

\section{RESUME}

Faisant suite à nos investigations antérieures relatives à l'évaluation in vitro de l'activité antifongique, cette étude s'est focalisée sur la mise en évidence du pouvoir inhibiteur des extraits des feuilles fraîches et sèches d'Ageratum conyzoides, de Basella alba et de Mitracarpus villosus sur la souche de Lasiodiplodia theobromae, champignon responsable de la pourriture brune de cabosse de cacao dans la région de Kisangani. En six répétitions sur le milieu Patato dextrose agar, la souche de $L$. theobromae a été inhibée jusqu'à $68,1 \%$ par l'extrait aqueux de $B$. alba ; 60,0\% par l'extrait éthanolique d'A. conyzoides et 55,2\% par l'extrait éthanolique de $M$. villosus (tous obtenus des feuilles sèches). Seules les feuilles fraîches des extraits aqueux $(56,7 \%)$ et éthéré $(51,1 \%)$ de A. conyzoides ont révélé des pourcentages d'inhibition élevés par rapport à ceux des extraits des feuilles fraîches de $B$. alba et $M$. villosus. Les extraits des feuilles sèches ont présenté des pourcentages d'inhibition élevés suivis de ceux des feuilles fraîches et enfin de ceux d'extraits bruts après deux jours d'incubation. Ainsi, subsidiairement aux résultats escomptés, les plantes étudiées sont toutes actives. Ces pouvoirs inhibiteurs pourraient être très élevés pour les métabolites secondaires des plantes respectives.

Mots clés : Activité antifongique, Ageratum conyzoides, Lasiodiplodia theobromae, Basella alba, Mitracarpus villosus, Kisangani

\section{ABSTRACT}

Following our previous investigations relating to the in vitro evaluation of antifungal activity, this study focused on the demonstration of the inhibitory power of extracts of fresh and dry leaves of Ageratum conyzoides, Basella alba and Mitracarpus villosus on the strain of Lasiodiplodia theobromae, fungus responsible for brown rot of cocoa pod in the Kisangani region. In six repetitions on the Patato dextrose agar medium, the strain of $\mathrm{L}$. theobromae was inhibited up to $68.1 \%$ by the aqueous extract of B. alba; $60.0 \%$ by the ethanolic extract of A. conyzoides and $55.2 \%$ by the ethanolic extract of M. villosus (all obtained from dry leaves). Only the fresh leaves of the aqueous (56.7\%) and ethereal (51.1\%) extracts of A. conyzoides showed high inhibition percentages compared to those of the extracts of the fresh leaves of B. alba and M. villosus. The extracts of the dry leaves showed high inhibition percentages followed by those of the fresh leaves and finally those of crude extracts after two days of incubation. Thus, in addition to the expected results, the plants studied are all active. These inhibitory powers could be very high for the secondary metabolites of the respective plants.

Keywords: Antifungal activity, Ageratum conyzoides, Lasiodiplodia theobromae, Basella alba, Mitracarpus villosus, Kisangani 


\section{INTRODUCTION}

Over $40 \%$ of the world's population, $52 \%$ of them in Africa and Asia, benefit from agriculture, which is considered one of the main sources of income $[1,2]$. In this sector, the cultivation of Cacao theobromae tends to be predominant compared to that of cotton, sugar cane or tobacco. Africa alone today holds almost $70 \%$ of world production [3].

However, this cocoa activity is confronted with the fall in harvest due to fungi, in particular Lasiodiplodia theobromae. Reported for the first time on cocoa in Cameroon in $1895[4,5]$ and in South America in Ecuador [6], this pathogenic germ can cause the death of the tree over time [7]. The decline of the cocoa tree orchestrated by $L$. theobromae constitutes a permanent danger not only in India [8], Cameroon and Western Samoa, in the Philippines [9], but also in the Kisangani region of the Democratic Republic of Congo. Among the possible solutions to this scourge is common use and high concentrations of synthetic chemicals, which increases the risk of seeing toxic residues in fruits and/or leaves becoming poisonous over time.

Going through history, it has been found that herbal medicines have contributed enormously to the evolution of modern medicine $[10,11]$. About $50 \%$ of the therapeutic molecules used today are of natural origin (plants), nurseries of antimicrobial compounds and/or inhibitors of antibiotic resistance mechanisms [12]. Over $80 \%$ of the African population uses traditional medicine since it is accessible in terms of cost, proximity and abundance [13]. Indeed, several medicinal plants are used for their biological properties, such as Ageratum conyzoides, Basella alba and Mitracarpus villosus [14].

In addition, several works have highlighted the antimicrobial and/or antifungal potential of extracts from medicinal plants, which have proven to be effective and eco-friendly in the fight against phytopathogenic germs $[15,16,17]$. However, there are almost no studies on the use of plants against $L$. theobromae.

This is how we undertook a series of works on the research of medicinal plants and phytomolecules which can inhibit the growth of the $L$. theobromae strain. This is a saving path which goes hand in hand with the principles of the new regulations which discourage the use of synthetic fungicides [18, 19] and limit the potential risks for human health as well as pollution of the environment $[20,21]$
This work aims to evaluate in vitro the inhibition power of the four extracts (raw, aqueous, ethanolic and ethereal) from the fresh and dry leaves of $A$. conyzoides, $B$. alba and $M$. villosus on the strain of $L$. theobromae.

\section{MATERIALS AND METHODS}

\subsection{Study environment}

This study was carried out in the Kisangani region, the capital of the Tshopo Province in the Democratic Republic of Congo. The city of Kisangani is located at $0^{\circ} 31$ 'north latitude, from the Equator $(57 \mathrm{~km}), 25^{\circ} 11^{\prime}$ east longitude from the Greenwich meridian, and 428 meters above sea level [22, 23].

\subsection{Plants and treatment}

The leaves of A. conyzoides, B. alba and M. villosus were collected after being identified by the Herbarium service of the Faculty of Sciences of the University of Kisangani. These leaves were processed in the laboratory, in three different batches in order to obtain the raw extract from the pressed fresh leaves, the extract from the fresh macerated leaves and the extract from the dried macerated leaves. For this, $10 \mathrm{~g}$ of fresh vegetable matter or powder of dry leaves were macerated for 48 hours in $50 \mathrm{ml}$ of distilled water for the aqueous extract, $95 \%$ ethanol for the ethanolic extract and diethyl ether for the ethereal extract. The macerated filtrates were concentrated in an oven at $40{ }^{\circ} \mathrm{C}$, due to $2 \mathrm{~mL}$ of the concentrate from $10 \mathrm{~mL}$ of the macerated filtrate.

\subsection{Obtaining the fungal strain}

The $L$. theobromae strain was isolated from cocoa pods naturally affected by brown rot. These pods were harvested directly from the tree in the cocoa plantations of Bengamisa (37 km on the Kisangani-Buta highway) and Yangambi (90 $\mathrm{km}$ from the city of Kisangani). After washing the pods, a symptomatic piece was removed, washed with 5\% bleach and rinsed in sterile distilled water to finally be seeded on Patato dextrose agar (PDA) at $25^{\circ} \mathrm{C}$ in the dark for five days. Transplanting was carried out on PDA at $25 \pm 2^{\circ}$ $\mathrm{C}$ under permanent white light. To prevent the growth of bacteria, $100 \mu \mathrm{L}$ of Ampicillin $(50 \mathrm{mg} /$ $\mathrm{mL})$ and $100 \mu \mathrm{L}$ of Chloramphenicol $(50 \mathrm{mg} /$ $\mathrm{mL}$ ) were added beforehand to each $100 \mathrm{~mL}$ of PDA at $45^{\circ} \mathrm{C}$ before solidification. 
bioRxiv preprint doi: https://doi.org/10.1101/2020.12.09.418350; this version posted December 9, 2020. The copyright holder for this preprint (which was not certified by peer review) is the author/funder, who has granted bioRxiv a license to display the preprint in

\subsection{Evaluation of antifungal activity}

The antifungal activity was evaluated on the basis of percentage inhibition (PI) of mycelial growth or reduction of mycelial growth (RCM) of plant extracts on the strain of $L$. theobromae, with six repetitions. $12 \mathrm{~mL}$ of PDA were poured into each $90 \mathrm{~mm}$ diameter Petri dish. A line was drawn in advance on the median of the Petri dish, each studied extract was applied to one half and the mycelial explant $5 \mathrm{~mm}$ in diameter, was placed on the other half at $2.5 \mathrm{~mm}$ from the midline [24]. Mycelial growth was measured on either side of the midline (Fungal Ray, FR) every 24 hours until the Petri dish was filled. The negative control was carried out under the same conditions but without extract. Ampicillin and Gentamicin were used as positive controls.

The PI calculation was carried out by the formula

$$
\underline{\text { (FR negative control - FR Extract)X } 100}
$$

FR negative control

The $\mathrm{R}$ 3.4.0 software was used to compare the means of the PI by performing the one-factor variance analysis test (at the 95\% threshold). The standard deviation was evaluated in standard deviations represented in error bars on the histograms.

\section{RESULTS}

\subsection{Inhibition percentage}

\subsubsection{Extraction solvents}

Figure 1 below illustrates the IP of the extraction solvents against $L$. theobromae

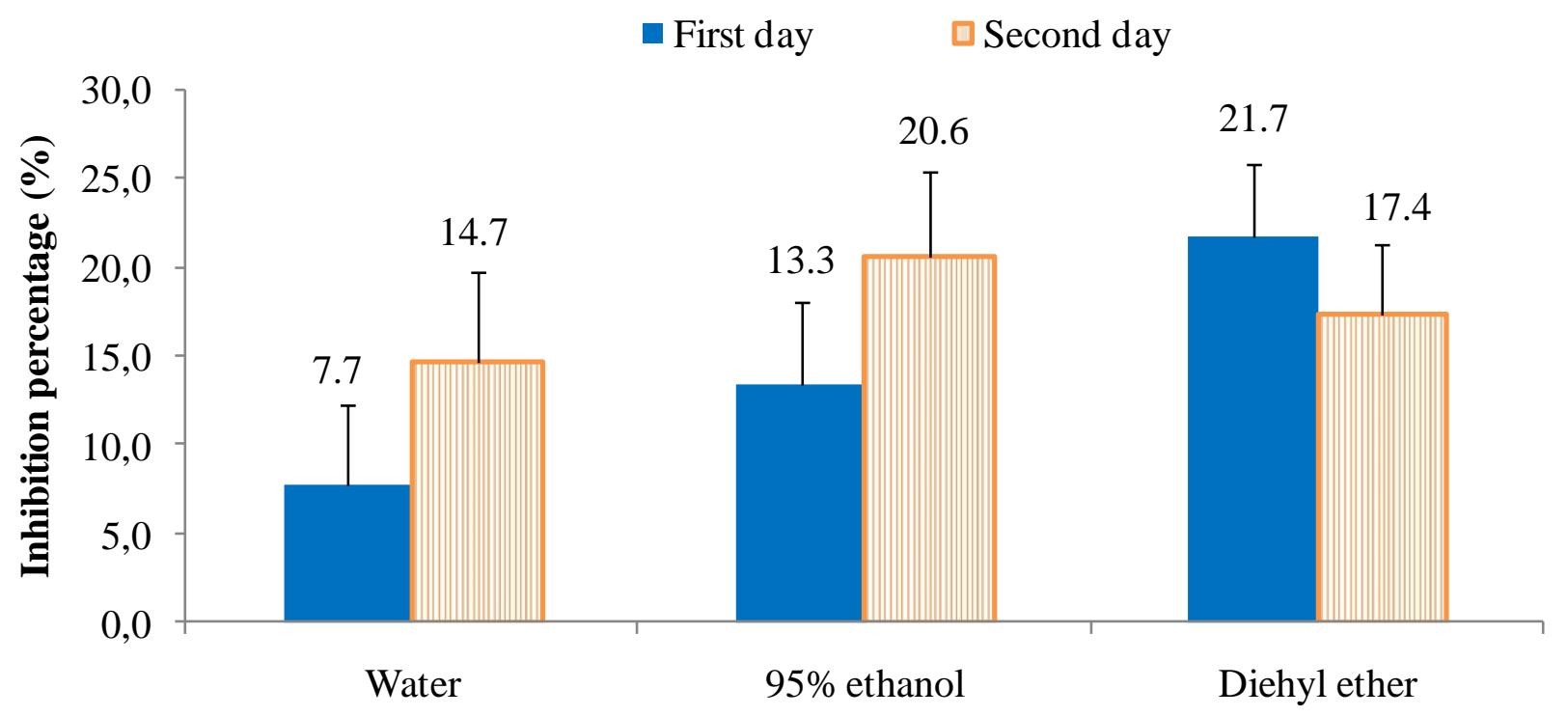

Solvants used

Figure 1: Percentage inhibition of water, $95 \%$ ethanol and diethyl ether on the L. theobromae strain

After one day of incubation, the diethyl ether achieved a high inhibition rate of $21.7 \%$ while the water achieved the lowest PI of 7.7\%. However after two days of incubation, the ethanol revealed a high PI at $20.6 \%$ while that of the water was low at $14.7 \%$.

\subsubsection{Extracts of fresh leaves}

Figure 2 below illustrates the antifungal activity of the fresh leaves of the plants tested, after a few days of incubation. 

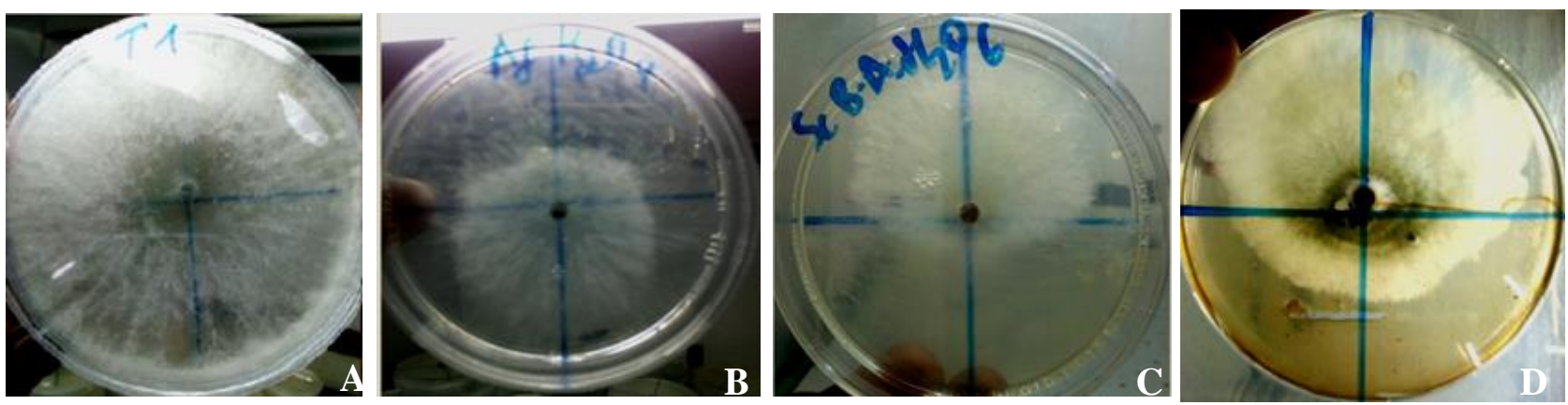

Figure 2: A: Negative control strain of L. theobromae (after 2 days of incubation), B: Aqueous extract of fresh leaves of A. conyzoides (after 2 days of incubation), C: Aqueous extract of dry leaves of B. alba (after 2 days of incubation) and D: Aqueous extract of dry leaves of M. villosus (after 4 days of incubation) against the strain of L. theobromae

It is obvious to note that the growth of the L. theobromae strain was not maximal for A. conyzoides, B. alba and $M$. villosus whereas it took just 2 days of incubation to achieve maximum growth for the negative control.

\section{a. Raw extracts}

The fresh leaves of the plants studied revealed PI values as illustrated in figure 3 below.

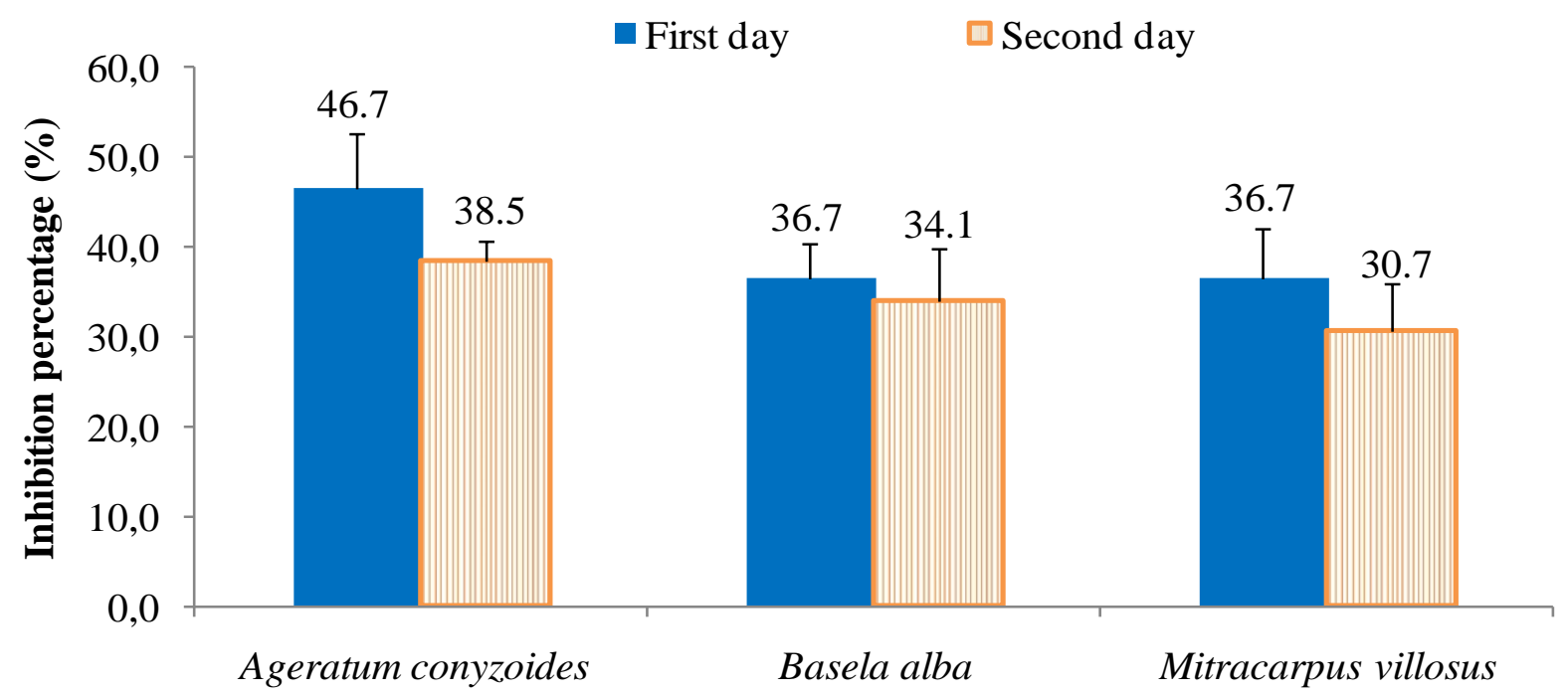

Plants used

Figure 3: Percentage inhibition of raw extracts of fresh leaves of A. conyzoides, B. alba and M. villosus on the strain of L. theobromae

The raw extract of fresh leaves of A. conyzoides has high PI during the two days of incubation, 46.8 and $38.5 \%$ respectively, whereas that of $M$. villosus had the lowest PI after two days, at $30.7 \%$.

\section{b. Macerated extracts}

The maceration of the fresh leaves in water, $95 \%$ ethanol and diethyl ether revealed the PI on the strain of $L$. Theobromae as illustrated in figure 4 below. 


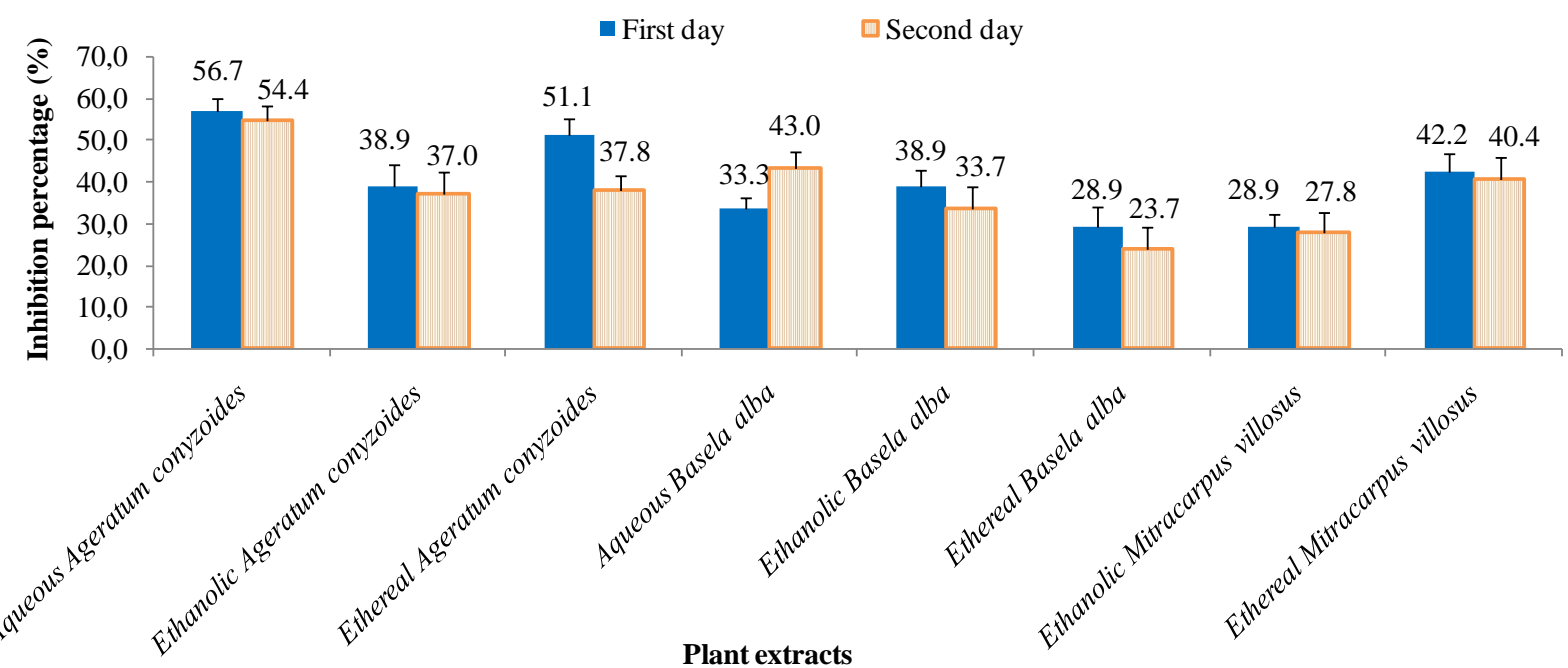

Figure 4: Percentage inhibition of extracts of fresh leaves of A. conyzoides, B. alba and M. villosus on the strain of L. theobromae

From this figure, it should be noted that the aqueous extract of $A$. conyzoides has higher PI after one day or $56.7 \%$ and two days of incubation or $54.4 \%$; followed by the ethereal extract of the same plant after a day of incubation (51.1\%). The ethereal extract of $B$. alba had the lowest PI after two days of observation, $23.7 \%$.

\subsubsection{Extracts of dry leaves}

The following figure 5 illustrates the PI of the aqueous, 95\% ethanolic and ethereal extracts of the dry leaves tested in vitro on the strain of $L$. theobromae.

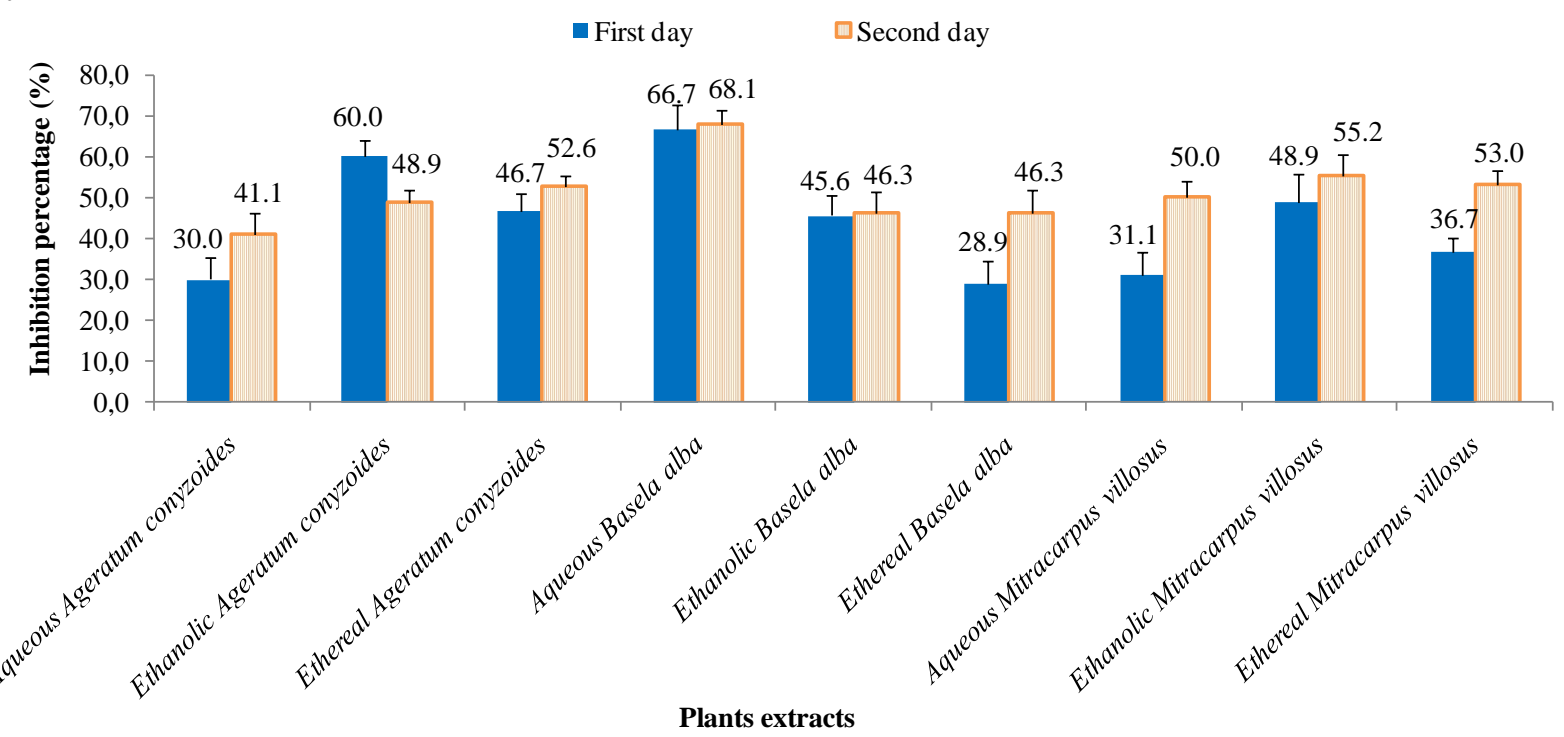

Figure 5: Percentage inhibition of extracts of dry leaves of A. conyzoides, B. alba and M. villosus on the strain of L. theobromae

It is obvious to observe from this figure that the aqueous extract of $B$. alba revealed a higher PI after two days of testing 68.1\% (66.7\% after one day), followed by the $95 \%$ ethanolic extract of $A$. conyzoides after one day of incubation, i.e. $60.0 \%$. The ethereal extract of $B$. alba was found to have the lowest PI at $28.9 \%$ after one day of incubation. 


\subsection{Maximum growth time}

The L. theobromae strain is supposed to reach its maximum growth by completely filling the Petri dish. Thus the times necessary to achieve this, called the maximum growth time MGT (in days) for each extract tested are shown in tables 1 and 2 below.

Table 1: Maximum growth time (in days) of the L. theobromae strain against extraction solvents and antibiotics (positive controls)

\begin{tabular}{|l|c|}
\hline Extraction solvent & Mycelial growth time (day) \\
\hline Negative control & 2 \\
\hline Distilled water & 3 \\
\hline Ethanol 95\% & 3 \\
\hline Diethyl ether & 3 \\
\hline Ampicillin & 4 \\
\hline Gentamicin & 4 \\
\hline
\end{tabular}

Table 2: Maximum growth time of the $L$. theobromae strain against the extracts of the plants studied

\begin{tabular}{|c|c|c|c|c|c|c|c|}
\hline \multirow{2}{*}{ Plants used } & \multicolumn{7}{|c|}{ Mycelial growth time (day) } \\
\cline { 2 - 8 } & Raw extract & Aqueous extract & \multicolumn{2}{|c|}{ Ethanolic extract } & \multicolumn{2}{c|}{ Ethereal extract } \\
\cline { 2 - 8 } & $\begin{array}{c}\text { Fresh } \\
\text { leaves }\end{array}$ & $\begin{array}{c}\text { Fresh } \\
\text { leaves }\end{array}$ & $\begin{array}{c}\text { Dry } \\
\text { leaves }\end{array}$ & $\begin{array}{c}\text { Fresh } \\
\text { leaves }\end{array}$ & $\begin{array}{c}\text { Fresh } \\
\text { leaves }\end{array}$ & $\begin{array}{c}\text { Fresh } \\
\text { leaves }\end{array}$ & $\begin{array}{c}\text { Dry } \\
\text { leaves }\end{array}$ \\
\hline Ageratum conyzoides & 4 & 4 & 4 & 3 & 4 & 3 & 4 \\
\hline Basela alba & 3 & 4 & 6 & 4 & 3 & 3 & 4 \\
\hline Mitracarpus villosus & 3 & - & 6 & 3 & 4 & 3 & 4 \\
\hline
\end{tabular}

The MGT of the L. theobromae strain is only 2 days for the negative control, 3 days for the solvents and 4 days for the antibiotics (Tab 1) like certain plant extracts. On the other hand, with the aqueous extracts of B. alba and M. villosus (Tab 2), it took 6 days to reach maximum growth.

\subsection{Water content}

Figure 6 below illustrates the water contents of the fresh leaves of the plants studied after their drying.

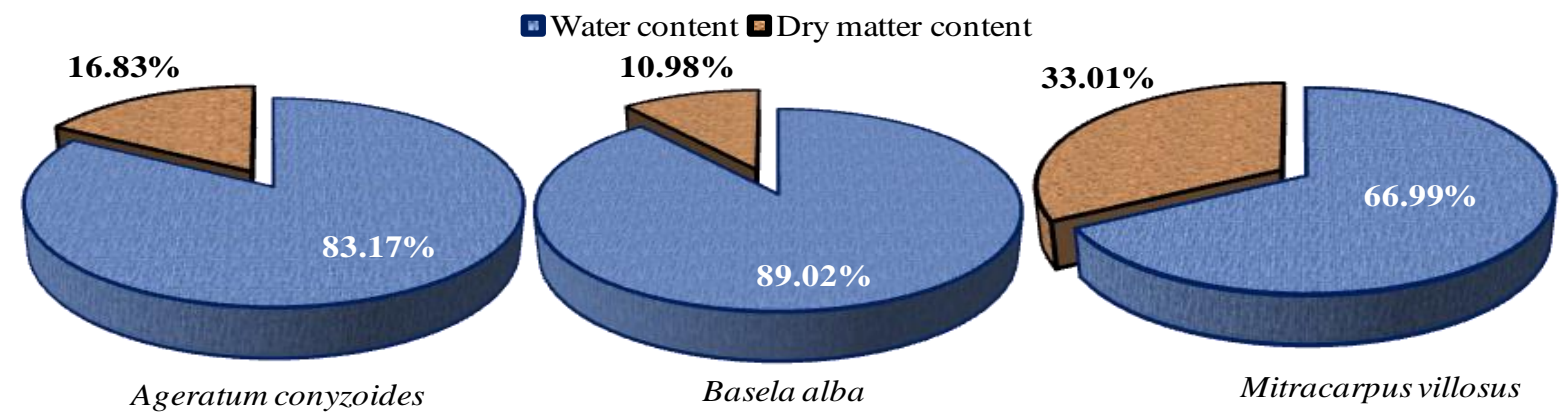

Figure 6: Water content of fresh leaves of A. conyzoides, B. alba and M. villosus

It emerged from this figure that the fresh leaves of $B$. alba are the richest in water, at $89.0 \%$ while those of $M$. villosus contain less, at $67.0 \%$.

\subsection{Total extract content}

The extraction yields after complete evaporation of the solvents from the maceration of the dried leaves are illustrated in the following figure 7 


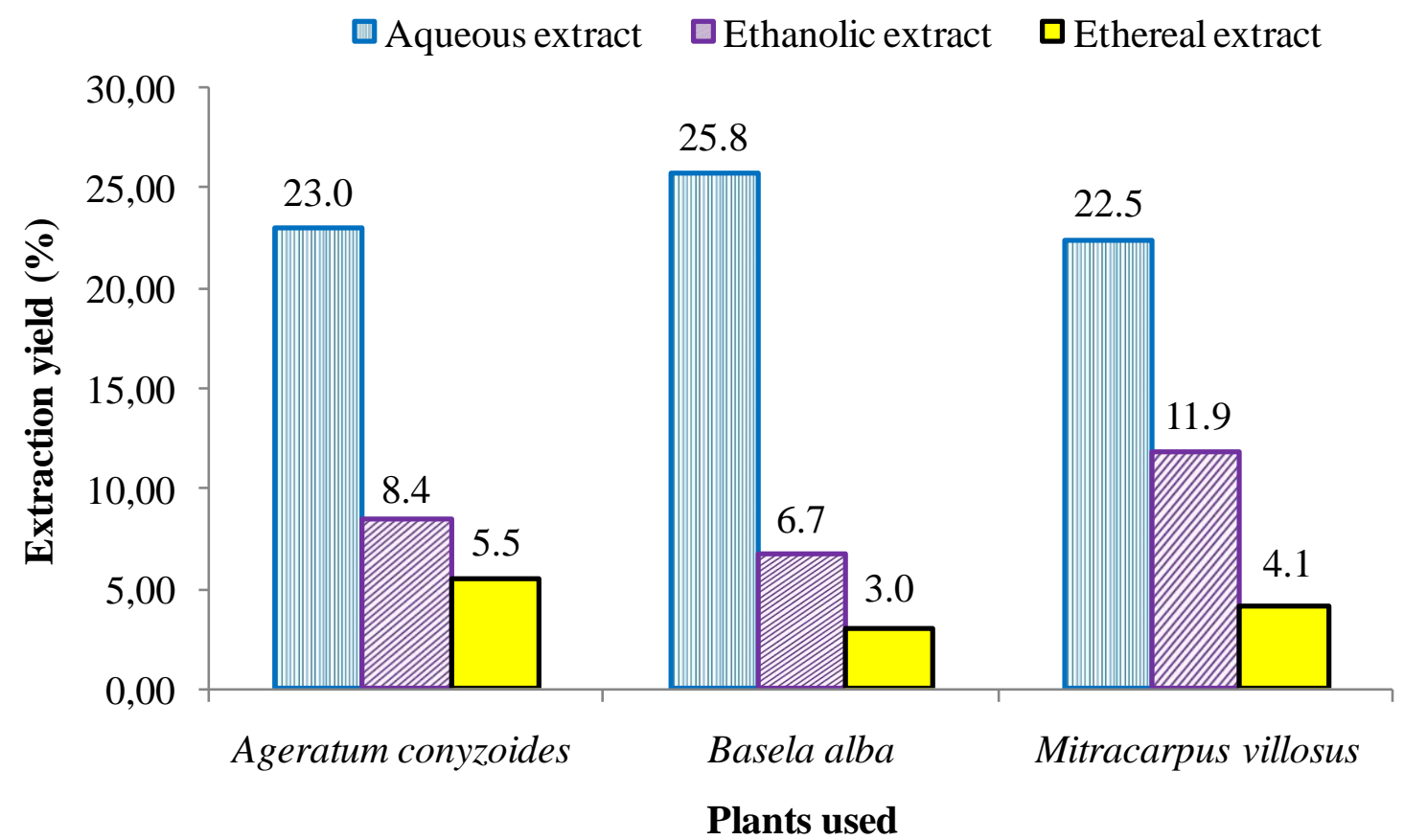

Figure 7: Yield in total extracts

The yield of aqueous extraction of $B$. alba is the highest at $25.7 \%$ followed by that of $A$. conyzoides at $23.0 \%$. Furthermore, the ethereal extraction yield of $B$. alba is the lowest, at $2.9 \%$.

\section{DISCUSSION}

As shown in our previous work, the growth of the $L$. theobromae strain was considerably slowed down when confronted to the extracts of the medicinal plants studied (Fig. 2). A prolongation of GMT was found significantly for the tests with extracts, making them pass from 2 days of incubation for the negative control to 6 days in particular for the aqueous extracts of the dry leaves of $B$. alba and M. villosus. This same GMT for 6 days was observed for the raw extract of M. oleifera [25].

It has been proven that all the solvents used for the extractions (water, 95\% ethanol and diethyl ether) have PI showing significant differences in them ( $\mathrm{p}$ value $=0.00335)$ but have no antifungal activity (PI less than 25\%) according to Bouazza [24]. Furthermore, although ethanol is reputed to be an ideal disinfectant, nonetheless it has been qualified to be ineffective against $L$. theobromae.

The raw plant extracts all have high antifungal activities compared to the negative control, with PI values ranging from $30.7 \%$ on the second day of incubation for M. villosus to
$46.7 \%$ on the first day for $A$. conyzoides. Furthermore, the latter has a high inhibitory effect compared to those of Aloe vera: $29.6 \%$ on the second day and Newbouldia laevis: $36.3 \%$ on the second day, but has a lower PI than that of $M$. oleifera $(74,1 \%)$ after two days of incubation [25]. The raw extracts have significantly different PI ( $\mathrm{p}$ value $=0.00552$ on the first day and $\mathrm{p}$ value $=0.0348$ on the second day).

In general, the macerated fresh leaves of the plants studied have high PI on the first day of incubation but slightly low on the second day, with the exception of the aqueous extract of B. alba which goes from 33.5 to $43.0 \%$. The opposite has been observed for maceration of dry leaves for which the PI generally increase over time, except for the ethanolic extract of $A$. conyzoides which go from 60.0 to $48.9 \%$. This observation would be justified by the presence of very volatile compounds which would constitute the maceration of fresh leaves, in particular essential oils, which mean that over time, these extracts can lose their antifungal power to the advantage of mycelial growth. As for the maceration of dry leaves, this 
observation would be due to the presence of non-volatile compounds.

Thus it would be preferable to note the results of evaluation of the antifungal activity of volatile compounds (essential oils for example) on the first and second day of incubation, but only on the second day for non-volatile compounds (tannins, alkaloids, saponins , etc.)

The PI of macerated dry leaves are all higher than those of macerated fresh leaves. This would be justified by the fact that in the dry leaves, the extractable matter is in greater quantity than in the fresh leaves following the evaporation of water which the latter contained before drying [25].

It is also necessary to indicate the essential role played by extraction solvents in the selection of the compounds contained in the plants studied. This is the case, for example, of B. alba, whose aqueous extract of the dry leaves has a PI of $68.1 \%$ on the second day, while the ethanolic and ethereal extracts produced $46.3 \%$ inhibition each. There have been very significant differences between different extracts when they are all from the same plant.

Fontem had reported that $M$. villosus (type of extract not reported) had a 64\% PI on Colocasia esculenta [26]. In the present work, the $95 \%$ ethanolic extract of the dry leaves of $M$. villosus has a PI of $55.2 \%$ on L. theobromae on the second day. This decrease in PI is due to the high virulence of $L$. theobromae compared to Colocasia esculenta.

Manal had observed a PI of $28 \%$, for a concentration of $8 \mathrm{mg} / \mathrm{mL}$ of aqueous extracts of Lavandula officinalis, $41 \%$ for Thymus vulgaris, $43 \%$ for Cymbopogon citratus against Botrytis cinerea, fungus responsible for gray rot of tomatoes in Morocco [27]. All these values are low compared to the PI of aqueous extract of the dry leaves of $B$. alba on the second day $(68.1 \%)$ and those of the aqueous $(54.4 \%$ on the second day) and ethereal (51.1\% on the first day) extract of fresh leaves of $A$. conyzoides.

Macerated fresh leaves of $A$. conyzoides have higher PI, notably the aqueous extract, $56.8 \%$ and $54.4 \%$ respectively on the first and second day, followed by ethereal extract on the first day, $51.2 \%$, while the antifungal activity of the raw extract of $A$. conyzoids on the first day was $46.7 \%$. This plant is of fungistatic interest being among the active plants if one takes into account its PI which are between 50 and $75 \%$ [24]. Indeed, the latter would contain bioactive molecules because it is cited in several works for its activity on other pathogenic germs. According to Adjou it is used against Aspergillus flavus, Aspergillus parasiticus, Aspergillus ochraceus, Fusarium oxysporum [28]. For Djeneb [29] A. conyzoides has an antifungal activity against Candida Albicans, a zoopathogenic germ while Ndjouondo [30] indicates its role as an antibiotic.

From the standpoint of classification of plants with antifungal activity, in addition to $A$. conyzoides, $B$. alba is also active against $L$. theobromae taking into account the PI threshold observed, ie $68.1 \%$ on the second day for the aqueous extract $[31,32]$. M. villosus, can be considered as an active plant but not at the same level as the first two plants against the fungus studied according the results obtained in present investigation.

The positive controls Ampicillin (42.9\%) and Gentamycin $(57.8 \%)$ all achieved lower PI than that of $95 \%$ ethanolic extracts of $A$. conyzoides : $60.0 \%$ (on first day) and aqueous extract of B. alba : $68.1 \%$ on second day (from dry leaves).

As in our previous investigations [25], the yields of aqueous extracts are far higher than those of ethanolic and ethereal extracts. Indeed, on the basis of the "like disolves like" principle, water, which is the universal solvent, generally dissolves a greater number of substances than any other solvent, in particular polar substances [33].

On the one hand, the yield of aqueous extract $(23.0 \%)$ of $A$. conyzoides is higher compared to that obtained by Adjou, ie $15.01 \%$ [28], but for the same plant, its yield of ethanolic extract $(23.58 \%)$ is higher than that found in this study $(8.4 \%)$ on the other hand.

According to the results obtained by Kambou [34], Mitracarpus scaber has a yield of $4 \%$ for the ethanolic extract, a low yield compared to that of $M$. villosus in the present work $(11.9 \%)$, but that of aqueous extract (5.3\%) of $M$. scaber is higher than that of $M$. 
villosus (4.1\%). These differences would depend on the species of the plants studied.

Mitracarpus scaber has a yield of ethanolic extract (4\%) is lower than and aqueous extract $(5.3 \%)$ obtained by Kambou [34]. All these values are much lower than those of M. vullos is whose ethanolic extract yield is $11.10 \%$ and that of aqueous extract $20.80 \%$. These differences would be due to the chemical composition of the species of the plant studied.

The water contents of B. alba (89.02\%) and $A$. conyzoides $(87.34 \%)$ are all higher than those of M. oleifera (74.2\%) [22] and even that of $M$. oleifera found by Broin, 75\% [35], of $N$. laevis $(75.3 \%)$ but are lower than that of $A$. vera $(93.3 \%)$ found previously [22]

Tsopmbeng obtained a low yield of aqueous extract (21.20\%) of Cupressus lusitanica [36] compared to our results of aqueous extract of $B$. alba, $(23.16 \%)$. It should be emphasized that the aqueous extraction yields of $A$. vera $(15.4 \%)$ and $M$. oleifera (17.0\%) and $N$. laevis (8.1\%) [22] are all low compared to those of the plants studied in this work.

From the results obtained, very significant differences emerged between the PI of ethereal ( $\mathrm{p}$ value $=0.00218)$, ethanolic $(\mathrm{p}$ value $=$ 0.00987 ) and aqueous ( $\mathrm{p}$ value $=5.95 . \mathrm{e}-08)$ dry leaves. It is therefore important, in our next investigations to make a bio-guided fractionation to identify and extract the phytochemical groups responsible for the antifungal activity of these plants.

\section{CONCLUSION}

The aim of this work was to evaluate, in vitro, the inhibitory power of extracts of fresh and dry leaves of Ageratum conyzoides, Basella alba and Mitracarpus villosus on the strain of Lasiodiplodia theobromae isolated from brown cocoa pod. It appears that all the extracts of the plants studied are active and have a fungistatic character according to the method used.

The high percentages of inhibition were observed for the extracts of dry leaves including that of the aqueous extract of $B$. alba (68.1\% after two days of incubation), of the ethanolic extract of A. conyzoides (60, $0 \%$ after one day of incubation) and of the ethanolic extract of $M$. villosus $(55.2 \%$ after two days of incubation). The extracts of the fresh leaves revealed average percentages of inhibition, in particular that of the aqueous extract of A. conyzoides (56.7 and $54.4 \%$ respectively after one and two days of incubation) and that of the ethereal extract from the same plant $(51.1 \%$ after one day of incubation). A more dominant threshold of percentage inhibition could be observed for the secondary metabolites contained in these medicinal plants. Thus, our subsequent work will focus on the identification and isolation of the main phytochemical groups of these plants in order to assess their respective antifungal activities on the strain of $L$. theobromae.

\section{ACKNOWLEDGEMENT}

Professor Geert Baert of the University of Ghent/Belgium and North Coordinator of VLAAMSE INTERUNIVERSITAIRE RAAD (VLIR-UOS)/University of Kisangani: for assistance in the acquisition of some laboratory equipment and especially during an internship at the University of Ghent.

NKFUTELA EWALA Michel for his scientific and deontological contribution.

\section{REFERENCES}

1. Momagri, 2016. Chiffres-clés de l'Agriculture, http:// www.momagri.org/FR/chiffres-cles-de-1agriculture/ Avec-pres-de-40\%25-de-lapopulation-activemondiale-l-agriculture-est-lepremier-pourvoyeur-demplois-de-laplanete_1066.html, (20/09/2017).

2. Yarou, B.B., Pierre Silvie, Françoise Assogba Komlan, Armel Mensah, Taofic Alabi, François Verheggen et Frédéric Francis, 2017. Plantes pesticides et protection des cultures maraichères en Afrique de l'Ouest (synthèse bibliographique). Biotechnol. Agron. Soc. Environ. 2017 21(4), 288-304.

3. Tano, A.K.K, 2019 : «Production de Cacao dans le monde» disponible sur http://cacao.ci/category/statistiques 
4. Khanzada, M.A, Lodhi, AM and Shahzad, S, 2004. Mango dieback and gummosis in Sindh Pakistan caused by Lasiodiplodia theobromae. Plant Health Progress On-line http://www.plantmanagementnetwork.org.

5. Ko, WH, Wang IT, and Ann, P.J., 2004. Lasiodiplodia theobromae as a causal agent of kumquat dieback in Taiwan. Plant Disease88, 1383.

6. Griffon, W. M. et Maublanc, A., 1909: Sur une maladie du cacaoyer. - Bull. Soc. Mycol. France 25: 51-58.

7. Thevenin, J.-M., Ducamp M.et PaulinD., 2009. Conditions de développement de symptômes de Lasiodiplodia. Conférence internationale sur la recherche cacaoyère, 1621/11/2009.

8. Kannan, C., Karthik M. and Priya K, 2010. Lasiodiplodia theobromae causes a damaging dieback of cocoa in India. Plant Pathol 59:410

9. Dionisio, G. A. and Frances, L.M.G., 2017. Lasiodiplodia theobromae causes vascular streak dieback (VSD)-like symptoms of cacao in Davao Region, Philippines. Australasian Plant Dis. Notes (2017) 12: 54 Doi 10.1007/s13314-017-0279-9

10. Mohamed, H.F., 1991. Isolation and identification of pharmacologically active compounds from plants used in Somali traditional medicine. Comprehensive summaries of dissertation from the faculty of pharmacy, 75 . Acta universitatis UPSALIENIS, $6 \mathrm{p}$

11. Telefo, P.B., Lemfac, kM.C., Bayala, B., Lienou, L.L., Goka, C.S., Yemele, M.D., Mouokeu, C., Tagne, S.R. and Moundipa, F.P., 2012. Phytothérapie, Springer-Verlag France 2011 DOI 10.1007/s10298-011-0678-6. Article de synthèse Ethnopharmacologie

12. Toure, D. M. 2015. Etudes Chimique et Biologique des huiles essentielles de quatre plantes aromatiques médicinales de cote d'ivoire. HAL Id: tel-01222964 https://tel.archives-ouvertes.fr/tel-01222964

13. Sofowora, A. 1993. Medicinal Plants and Traditional Medicine in Africa, 2. Spectrum Books Limited, Ibadan, Nigeria, p. 289.
14. Ngongolo, K., Mtoka S., Kudzai M. and Mahulu A., 2014. Floral visitors of the Ageratum conyzoides in Amani Nature Reserve, Tanzania.

15. Galani, Y.J.H., 2008. Potentiel antifongique des extraits de sept plantes camerounaises contre Phytophtore infestans pathogène responsable du mildiou des Solanacées. Université de Leeds, Doi : 10.13140/RG.2.1.1189.3924.

16. Djeugap, J. F., Fontem D. A. et Tapondjou A. L. 2011. Efficacité in vitro et in vivo des extraits de plantes contre le mildiou (Phytophthora infestans) de la morelle noire. Int. J. Biol. Chem. Sci. 5(6): 2205-2213, 2011. Available online at http://ajol.info/index.php/ijbcs

17. Manasfi, Y. 2018. Lutte contre les pathogènes telluriques en contexte horticole: cas du pathosystème Choisya ternatal Phytophthora spp. (Thèse de doctorant) Université de Rouen Normandie. Available onHAL Id: tel-01716367 https://tel.archivesouvertes.fr/tel-01716367

18. Spotts, R.A. \& Cervantes, L.A., 1986.Populations, pathogenicity, and benomyl resistance of Botrytis spp., Penicillium spp., and Mucor piriformis in packinghouses. Plant Disease, 70, 106-108.

19. Avenot, H., Morgan, D.P. and Michailides, T.J., 2008.Resistance to pyraclostrobin, boscalid and multiple resistance to pristine (pyraclostrobin + boscalid) fungicide in Alternaria alternata causing Alternaria late blight of pistachios in California. Plant Pathology, 57, (1), 135-140.

20. Krieger, R.I., 2001.- Handbook of pesticide toxicology, 1 - Principles, 2nd ed. San Diego, CA, Academic Press, 1908 p.

21. Unnikrishnan, V. \& Nath B.S., 2002.Hazardous chemicals in foods. Indian J. Dairy Biosci., 11, 155-158.

22. Monusco, «Ville et Population de la RDCongo », 2003 [Online]: Available: http://monusco.unmissions.org/Default.aspx?ta bid $=11204 \&$ (juin ,2015)

23. Nshimba, S., 2008. Etude floristique, écologique et phytosociologique des forêts de 
l'ile Mbiye à Kisangani, R.D.Congo. Thèse de doctorat inedite, ULB, $255 \mathrm{p}$.

24. Bouazza F. et Hassikou R., 2011. Activité antifongique in vitro de la pulpe foliaire d'Aloe vera. Bull. Soc. Pharm. Bordeaux, 150(1-4), 95-106

25. Kwembe, J.T.K, Mbula, J.P, Onautshu, O., Mpiana, P.T, and Haesaert, G., 2020. Evaluation in vitro d'activité antifongique d'Aloe vera, de Moringa oleifera et Newbouldia laevis sur la souche de Lasiodiplodia theobromae dans la Région de la Kisangani/RDCONGO. ISSN 2412-9771 (Print) ISSN 2412-897X (Online). Sch Bull, May, 2020; 6(5): 111-118

26. Fontem, L.A., Chikoye, D., Fokunang, C. and Ndifon, E.M. 2013 : Weeds as potential biopesticides in Taro leaf blight disease management. Research Application Summary pp: $313-316$

27. Manal, K., Aourach, M., El Boukari, M., Barrijal, S. et Essalmani, H., 2017. Efficacité des extraits aqueux des plantes aromatiques et médicinales contre la pourriture grise de la tomate au Maroc. Biologie et pathologie. Comptes Rendus Biologies 340 : 386-393.

28. Adjou, E. S. et Soumanou, M. M., 2013. Efficacité des extraits de plantes dans la lutte contre les moisissures toxinogènes isolées de l'arachide en post-récolte au Bénin. Journal of Applied Biosciences 70:5555- 5566.2

29. Djeneb, C., Kouadio, B., Goueh G., N'guessan B.Y.F., Guédé N.Z., 2016. Etude Ethnobotanique, Evaluation de l'activite antifongique sur Candida albicans et de la toxicite sur des cellules hff de Bersama abyssinica (fresen.), une plante de la Pharmacopee Ivoirienne. European Scientific Journal January 2016 Edition vol.12, no.3 ISSN: 1857 - 7881 (print)

30. Ndjouondo, G.P., Ngene, J.P., Ngoule C.C., Kidik P.M-C., Ndjib R.C., Dibong S.D. et Mpondo M.E., 2015. Inventaire et caractérisation des plantes médicinales des sous bassins versants Kambo et Longmayagui (Douala, Cameroun). Journal of Animal \&Plant Sciences, 2015. Vol.25, Issue 3: 38983916 Publication date 31/7/2015, http://www.m.elewa.org/JAPS;
31. Abdellatif, S., A. Rahman, S.M. and Deraz, S.F.; 2011. Promising antifungal effect of some folkloric medicinal plants collected from el-hammam habitat, Egypt against dangerous pathogenic and toxicogenic fungi. ARPN Journal of Agricultural and Biological Science 6 (9): 26-32.

32. Hajji, H., Tallal I., Maafa, I., Bentata, F., Faris, F.E. EL A., Abdennebi, EL. And Elaissami, A., 2016. Evaluation in vitro de l'activité antifongique de quatre plantes médicinales marocaines sur cinq champignons phytopathogènes. Revue Marocaine de Protection des Plantes, 10: 57-65

33. Mpiana, P.T. 2015. Biophysique médicale, tome 1, édition Résud, Kinshasa/République Démocratique du Congo.

34. Kambou, Y.S.E., 1999. Contribution à l'étude de l'activité antifongique de Mitracarpus scaber Zuee (Rubiaceae). Université de Ouagadougou. Thèse Inédit, P.28

35. Broin, M.P., 2005. Composition nutritionnelle des feuilles de Basella alba. In Moringanews, available on http://www.moringanews.org/documents/Com pofeuilles.pdf

36. Tsopmbeng, N.G., Megatche C., Pitagor J, Lienou A.J, Yaouba A., Djeugap F.J. and Fontem D.A, 2014. Évaluation des activités antifongiques des extraits de plantes contre Phytophthora colocasiae, agent causal du mildiou du taro (Colocasiaesculenta (L.) Schott). Journal of Applied Biosciences 81:7221 - 7232 . 